\title{
From the battlefield to the labour camp: archaeology of civil war and dictatorship in Spain
}

\section{Alfredo González-Ruibal*}

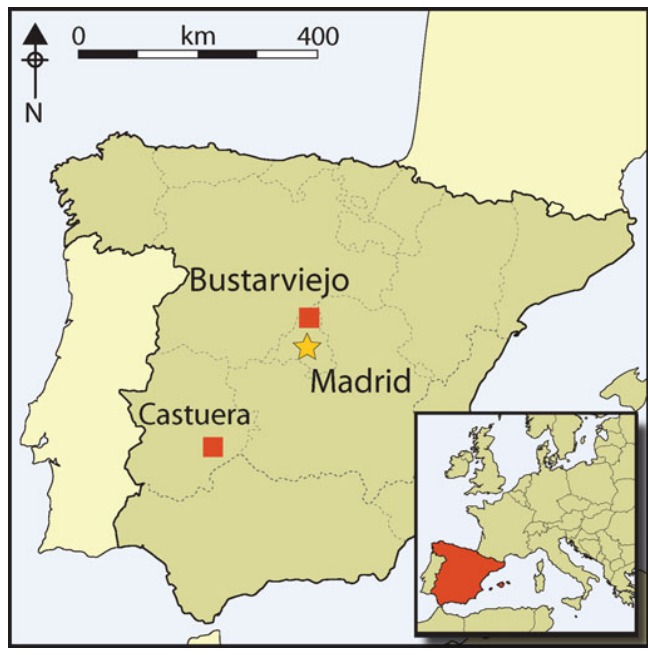

The author explores responses to political violence through the materiality of three aspects of the Civil War in Spain: military lines in the battle for Madrid, a concentration camp in Extremadura and a remote settlement of forced labourers and their families. He shows how archaeology's revelations reflect, qualify and enrich the story of human survival under the pall cast by a dictatorship. Sharing the inquiry with the public of today also revealed some of the disquieting mechanisms by which history is composed and how archaeology can be used to deconstruct it.

Keywords: Spain, twentieth century, war, conflict, social control, ideology, totalitarianism, Catholic Church

\section{Introduction}

Modern wars transform entire landscapes: from the trenches in the frontline to the internment camps and weapon factories in the rearguard, no place is spared (Saunders 2001; Schofield 2005: 19-20, 43-51). The material effects outlast the conflicts themselves and shape daily experiences and memories for decades. In the case of totalitarian regimes, spaces of internment often follow the end of hostilities and continue the politics of war in times of peace. Modern conflicts are messy. They blur the distinction between war and peace, combatant and non-combatant, producing hybrid sites: bombed civilian settlements, clandestine detention centres and guerrilla bases.

One of the most promising lines of enquiry in the archaeology of modern conflict addresses the complexities of entire landscapes altered by war (Saunders 2001; Schofield 2005;

* Institute of Heritage Sciences (Incipit), Spanish National Research Council (CSIC), San Roque 2, 15704

Santiago de Compostela, Spain 
Saunders \& Faulkner 2010). By studying landscapes and processes, instead of particular sites in isolation or categories of material culture, we are in a better position to grasp the logic and repercussions of twentieth- and twenty-first-century wars. "War in this period", Schofield (2005: 25) reminds us, "typically extended beyond the confines of a discrete battlefield, first to take in (and ultimately to take out) the entire landscape. . .extending to a global scale. . and impacting on everybody, however far from the front-line they may be". Following this perspective, my colleagues and I have been working since 2006 in different scenarios of the Civil War and post-war period in Spain. Recent exhumations of victims of political violence have once again highlighted repression in the Spanish Civil War (19361939) (cf. Ferrándiz 2006; Renshaw 2011), which claimed as many as 200000 lives (75 per cent of whom were Republicans). However, mass graves are only part of the picture. To fully understand the experience of the war and the logic of political violence, we must look beyond graves and examine battlefields, buildings, memorials and spaces of punishment: the entire geography of conflict that shaped the nation after the war began in July 1936.

The objectives of the research project on which this article is based were threefold: to create an archaeological account of the period, that is, to write history from things; to demonstrate the relevance of materiality in modern conflict; and to deconstruct a geography largely shaped by the subsequent politics of the victors' regime (1936-1975). In this article I will lead you through three archaeological landscapes that exemplify the cycle of conflict: a history of violence that starts with the siege of Madrid in November 1936 and ends in the same place with the closure of the forced labour camps 15 years later.

\section{The battle for Madrid}

In November 1936, only three months after their attempted military coup that provoked the Civil War, the Nationalist army arrived at the gates of Madrid. For the first time, the Republicans were able to stop the advance of Franco's Army of Africa, marching from the south (Reverte 2004). One of the neighbourhoods where this happened was the university campus. The Battle of Madrid began on 8 November 1936 and ended two weeks later with the Nationalist army deeply entrenched inside the campus but unable to proceed any further. For the rest of the war, the University was part of the frontline and a large part of it was devastated. After the war, a new landscape of commemoration began to be erected over the ruins, obliterating or concealing most traces of the war. The new architectural setting openly celebrated the triumph of the Francoist armies and mourned the Francoist dead. The Battle of Madrid itself (actually a fiasco for the Nationalists) was largely forgotten. This overtly totalitarian landscape was gradually accepted as normal by the citizens of the capital (Figure 1).

In November 2008, we began to research the once-forgotten traces of the war, which, surprisingly, proved to be plentiful and ubiquitous (González-Ruibal et al. 2010). The act of retrieving these remnants was rewarded with another version of the past, owed to another way of exposing it. The project was designed to locate trenches in order to sample the materiality of both Nationalist and Republican soldiers.

Figure 2 shows part of a Republican trench system explored by archaeological excavation. The system was a long, linear defence, of a type widely employed by the Allies in the 


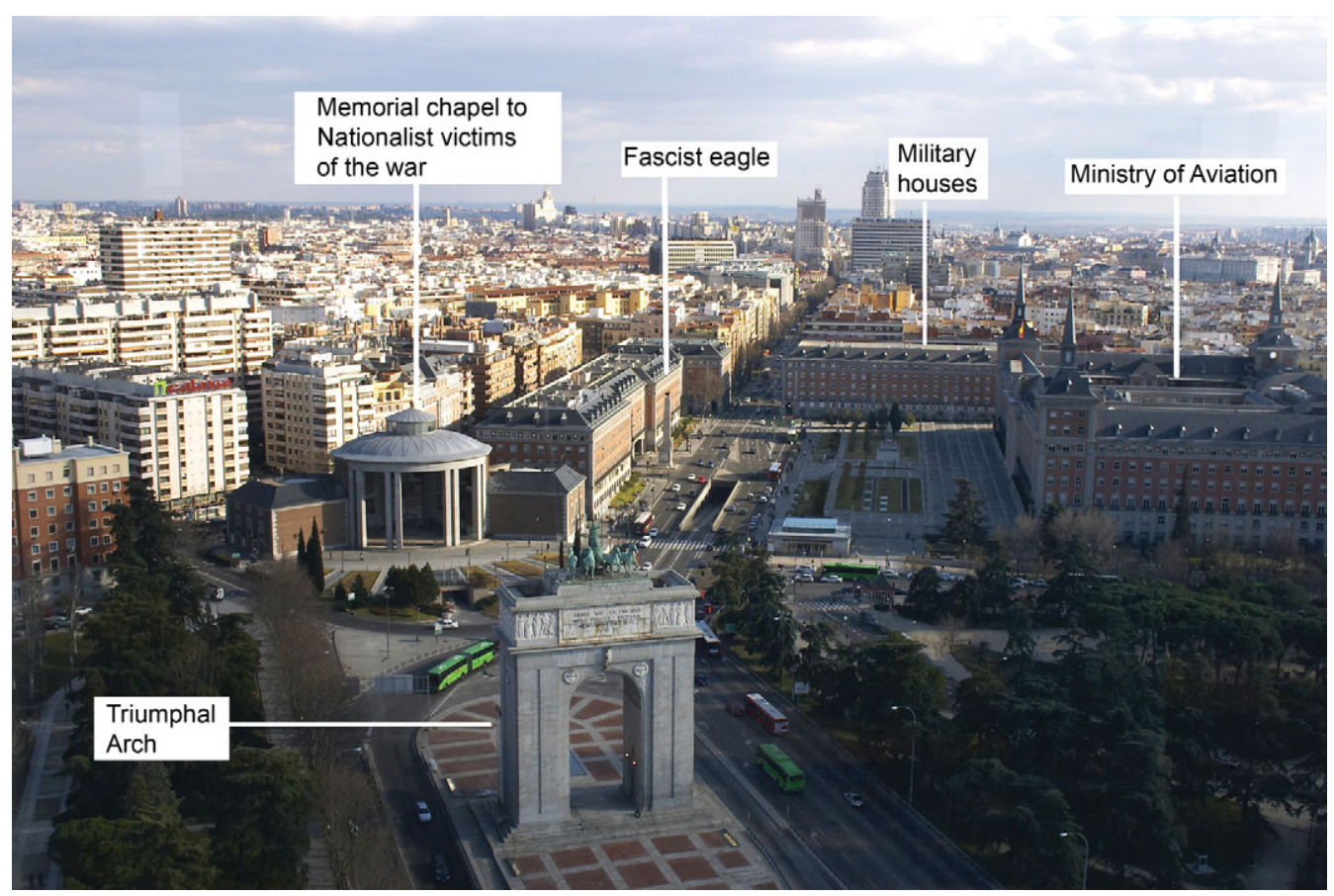

Figure 1. The entrance to the university campus reconstructed in Spanish fascist and neo-traditional style after the war (1940-1965).

First World War. The shelters were not state of the art: they were built using construction debris and their entrances faced the enemy, despite the obvious danger that this represented. There were traces of the first combatants around Madrid during late 1936, in which the International Brigades were involved. Evidence includes fragments of hand grenades, indicating close combat (absent from this area after January 1937), and ammunition of the type used by Brigadists: four 0.303 shell casings dated 1916 (from First World War surpluses). They were fired by the P14, a British rifle widely used by the International Brigades in Madrid in November 1936. We also found older ammunition, belonging to Remington and Vetterli Vitali rifles (Figure 3), both from the 1870s, and probably fired from Austrian rifles as noted by veterans of the battle (Arthur 2009: 217). Soviet supplies gradually replaced these archaic weapons. Five spent cartridges from a Mosin Nagant, with its magazine, appeared in situ on the floor of one of the sniper pits from 1938. Until the end, Republican troops were armed with a variety of weapons. This is clearly reflected in the archaeological record: we recovered cartridges of different calibres from half a dozen countries, including Germany. The Nazis sold some war materials to the Republic (Heiberg \& Mogens 2005: 167-68), but they might also have been captured from the enemy.

In general, shell casings and tin cans were few, probably because metal was systematically recycled. The command of the $7^{\text {th }}$ Division, which was in control of the campus, issued an order in May 1937 reminding the $40^{\text {th }}$ Brigade, garrisoned in our trench, that it was compulsory to "recover all spent shell casings and once collected they had to be returned to (C) Antiquity Publications Ltd. 


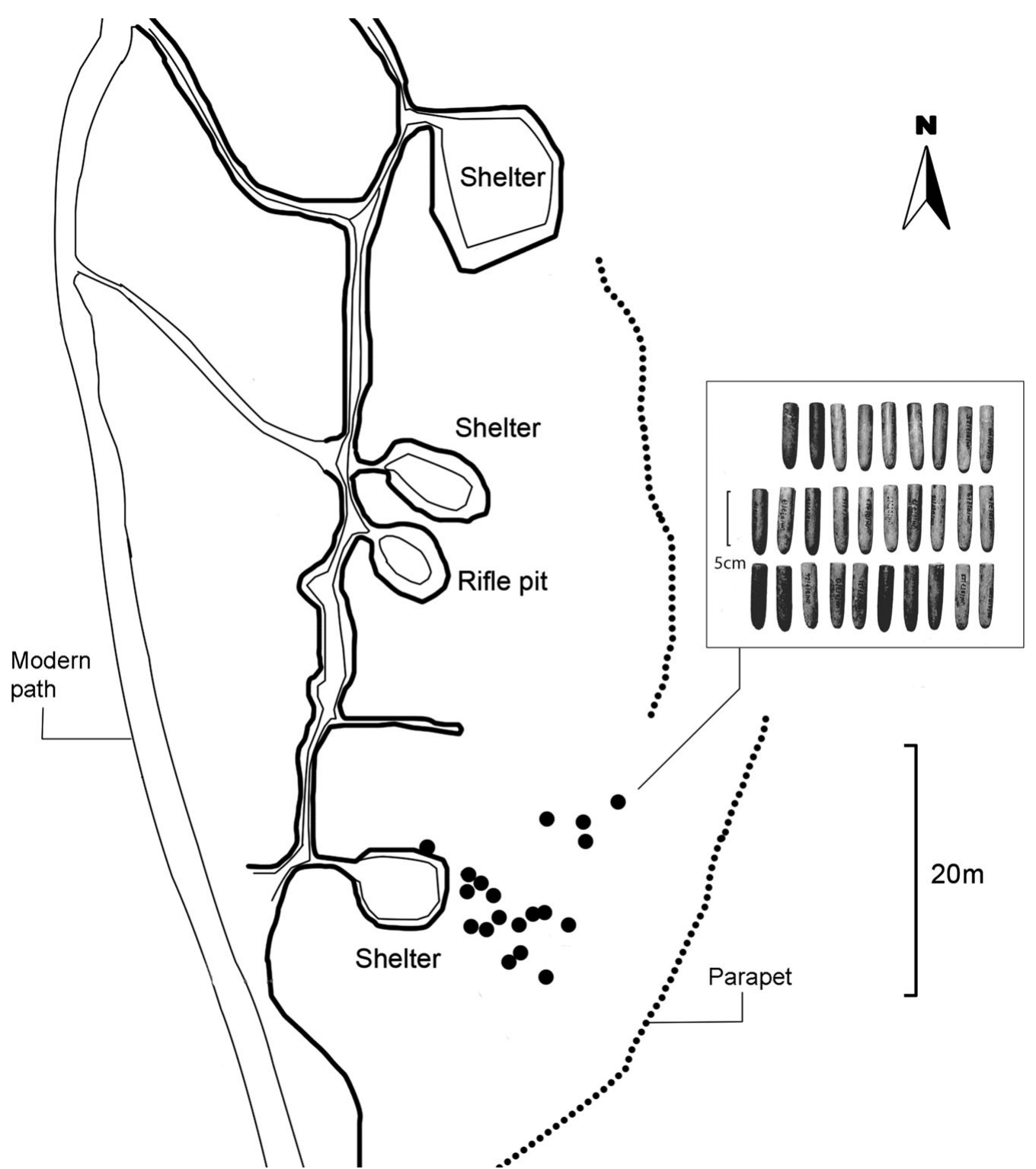

Figure 2. Map of the excavated trench and shelters, with indication of machine gun fire. Dotted lines indicate covered ways.

the officer in charge of ammunitions" (Quintero et al. in press). While the number of shell casings was scarce (31), fired bullets in and around the trench were numerous (151), the majority being Spanish $7 \mathrm{~mm}$ cartridges and German $7.92 \mathrm{~mm}$ : weapons issued to Franco's army (see below). The distribution of bullets shows a concentration immediately behind the main shelter (apparently due to a burst of machine gun fire; Figure 2). Shrapnel, in turn, concentrated on a covered way behind the trench. The quantity of fired bullets and shell

(C) Antiquity Publications Ltd. 


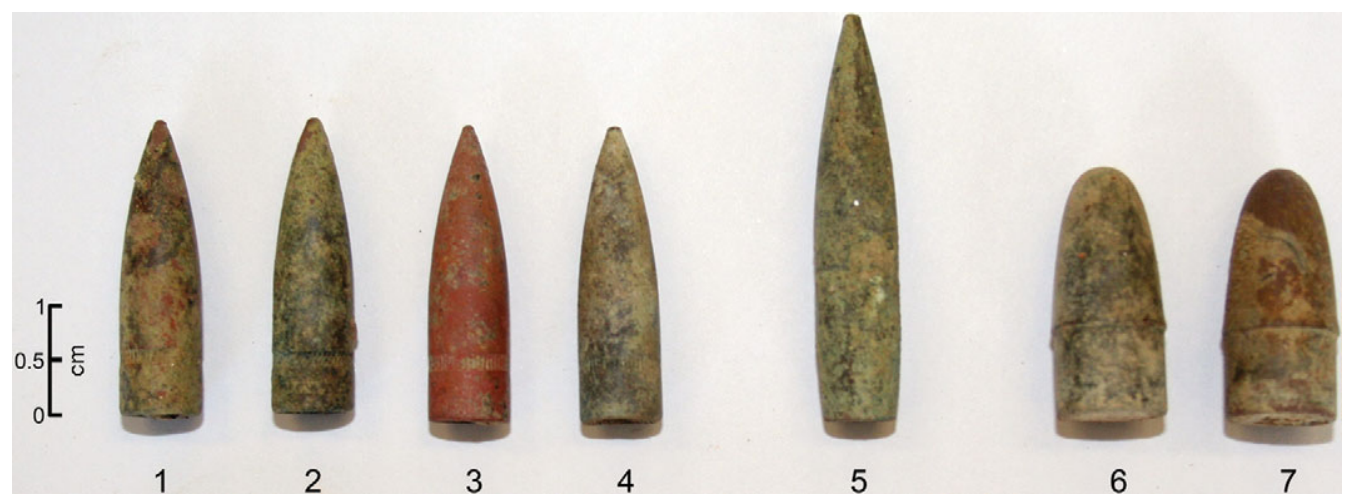

Figure 3. Ammunition from the Republican trench: 1-4) Soviet Mosin Nagant; 5) French Lebel; 6-7) Italian Vetterli Vitali.

fragments suggested that, despite being a stabilised front, the University of Madrid was far from quiet.

Evidence from the trench revealed an army in rags; instead of elements of military uniform, civilian items were found, especially boots and shoes. In one of the shelters was a small hearth, dug in the sandy ground and edged with pebbles, on which a tin of grease had been used as an improvised stove (Figure 4). The university fortifications were muddy and dirty; mattress springs, keyholes from drawers and door hinges showed that soldiers had tried to make themselves more comfortable with mattresses - which also provided good protection against shrapnel-and furniture from the bombed city. These must have given the trenches the appearance of a shanty town. An official document complained of the excessive 'domesticity' of some positions, which rendered them indefensible (Quintero et al. in press). Malaria, scabies and other diseases were rife in this insalubrious environment. Disparate combinations of artefacts remind us that not all objects are ideologically indicative (Figure 5).

An example of Nationalist lines was located in the small village of Abánades, on the Guadalajaran front, which witnessed an important battle in 1937-another thwarted attempt by the Nationalists to take Madrid. After the war, the region remained remote and rural as before, but was now littered with war debris. We excavated an isolated stronghold of the Nationalist army, constructed in concrete and steel (González-Ruibal 2011). Its location, on top of a hill, was typical of strategic practice in Morocco; an indication that Franco's army was waging war in Spain in the manner of a colonial conflict.

Around 100 tin cans were recovered, of which 21 per cent were of corned beef (Figure 6). All pieces of dress and equipment were army issue. We found remains from several military boots, belts and straps. Ammunition was plentiful. Differences with the Republican trench of the University of Madrid could not be greater. We discovered many shell casings but no incoming bullets, suggesting that the Nationalist soldiers were firing more than they were being fired upon-and were not recycling. There were only two types of cartridge: $7 \mathrm{~mm}$, of the type shot by the Spanish Mauser and Hotchkiss machine gun (78 per cent), and $7.92 \mathrm{~mm}$ for the German Mauser and Maxim machine gun (22 per cent). Markings show

(C) Antiquity Publications Ltd. 

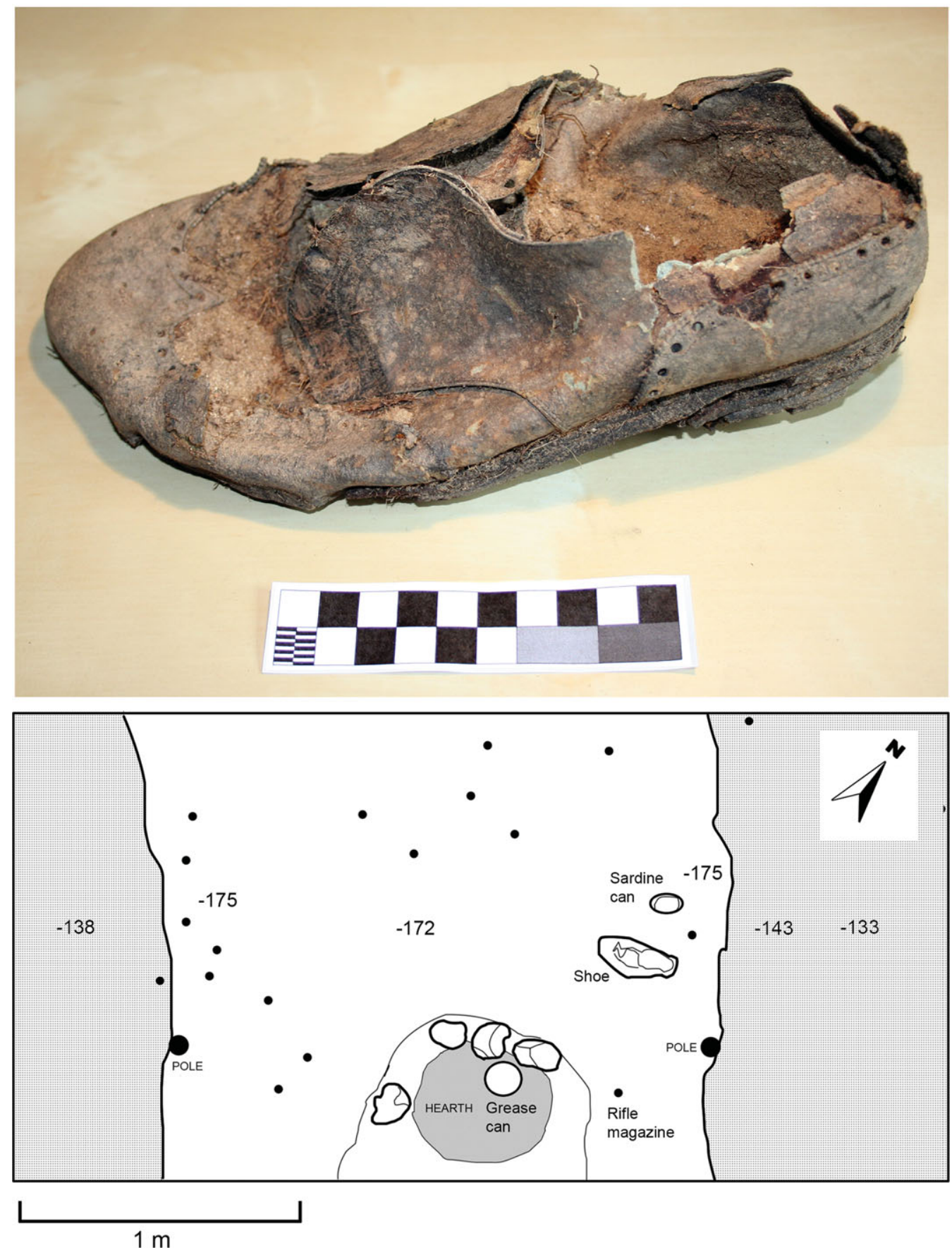

Figure 4. A man's shoe and the context of the find: inside a dug-out, near an improvised hearth.

(C) Antiquity Publications Ltd. 

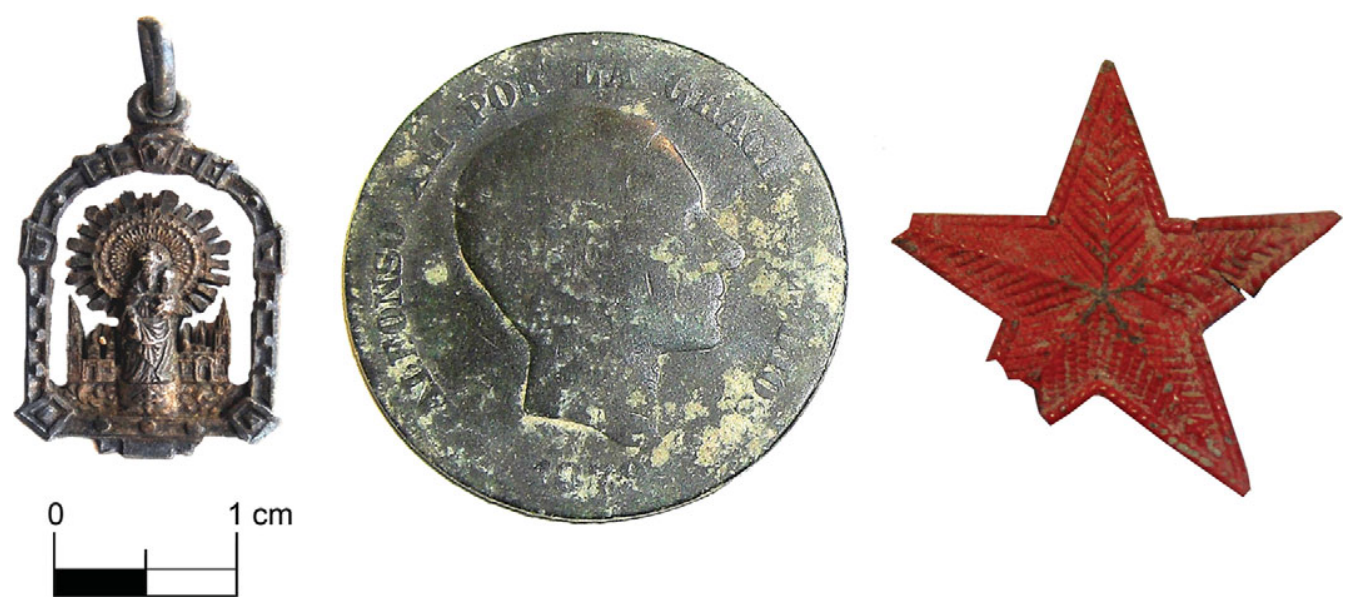

Figure 5. Unlikely partners in the Republican trench: a medal of the Virgin of Saragossa, a red star from a Republican uniform and a coin of the nineteenth-century king Alphonse XII who restored the monarchy following the First Spanish Republic.

that over half of the cartridges (51 per cent) were produced between 1936 and 1938: only one cartridge was surplus from the First World War.

Evidence from daily life in the trench is manifold: several paw-prints of a dog behind a track of military boots show that the garrison had a faithful pet in 1938. A cheap alloy earring found inside one of the shelters is perhaps a lost memento from a wife or girlfriend. A complete coffee set, including a coffee grinder, was found inside a covered trench. As in the University trenches, we found parts of drawers and other furniture. Inside the covered trench we found a complete Italian M-1915/16 helmet and, inside the shelters, a flare casing and motorcycle goggles, also Italian. In the village, one of the residents still has an Italian mess tin with the name of the owner on it_- "Armando Stellani”. These Italian finds reflect the presence of Mussolini's troops, who were known to have taken Abánades during the Battle of Guadalajara in February 1937, and exchanged part of their military equipment for Spanish clothes and handicrafts. Although there is a widespread belief that soldiers were uninterested in politics (Seidman 2002), we were able to document 20 graffiti in three sites in Abánades. Of these, 10 have political messages (8 Nationalist, 2 Republican) and show that many participants in the conflict were indeed politically involved (Figure 7).

The comparison between the Nationalist and Republican fortifications offered a marked contrast: while the former were well built in steel and concrete, the latter were basically rough stone walls resembling local housing. The differences were also clear in the materials recovered in our excavations: the plentiful supply of corned beef in the Nationalist trench compared with the shanty town of the Republican lines in the university.

There was also a contrast between the post-war embellishment of the university campus and the aftermath in the Guadalajara district. Engaging the present inhabitants of Abánades in our research showed that the war and its relict landscape were not regarded in a wholly negative light. This was partly due to their inheritance of war debris. While many Spaniards were suffering extreme poverty, local occupants here profited from the sale of unexploded ordnance, cartridges and steel beams. They systematically reused war materials: anti-tank (C) Antiquity Publications Ltd. 


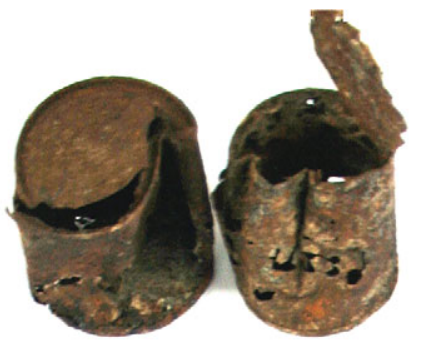

1
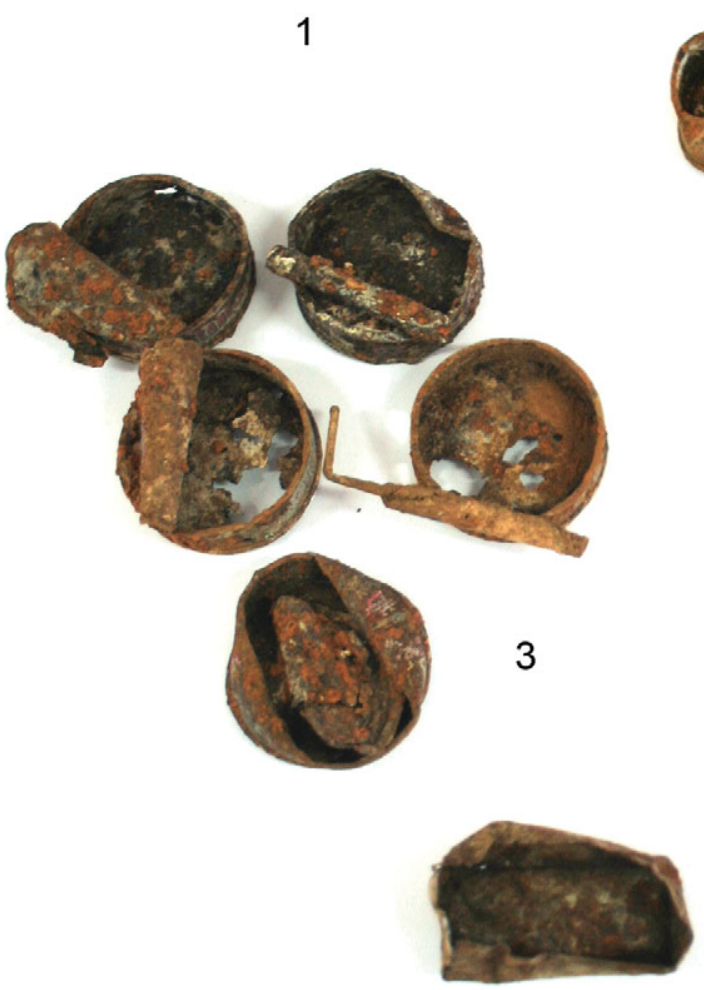

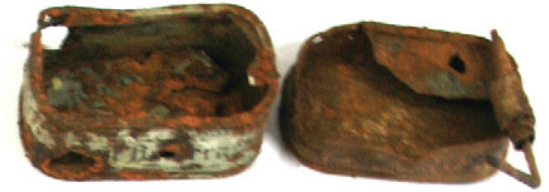

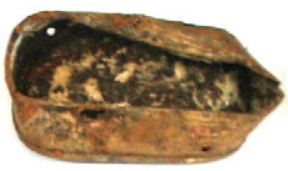

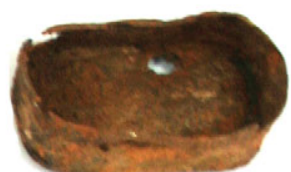

2

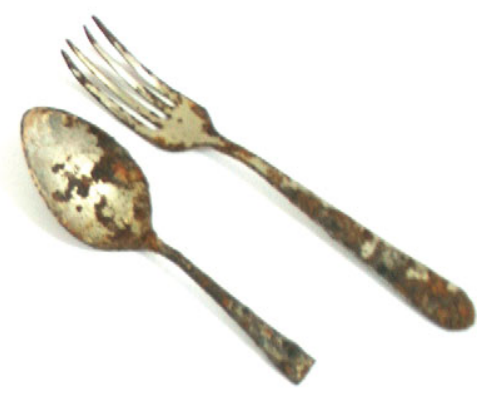

Figure 6. Eating in the trench: 1) condensed milk; 2) sardines; 3) tuna; 4) corned beef.

mines proved to be good containers for making soap, and ammunition boxes useful for storing tools. Bombs and grenades still decorate many homes and people remember looking for them when they were children. Moshenska (2008) has suggested that collecting war debris is a way of children's coping with conflict. For most children and teenagers, military rubbish in the post-war period also evoked epic stories, which resonated with tales of the 'National Crusade' taught at the school—a time in which their tiny village had played an important role in history. At Abánades, unlike the University of Madrid, the memory of the conflict was not erased: war ruins made the experience of landscape pleasurable for later generations.

(C) Antiquity Publications Ltd. 


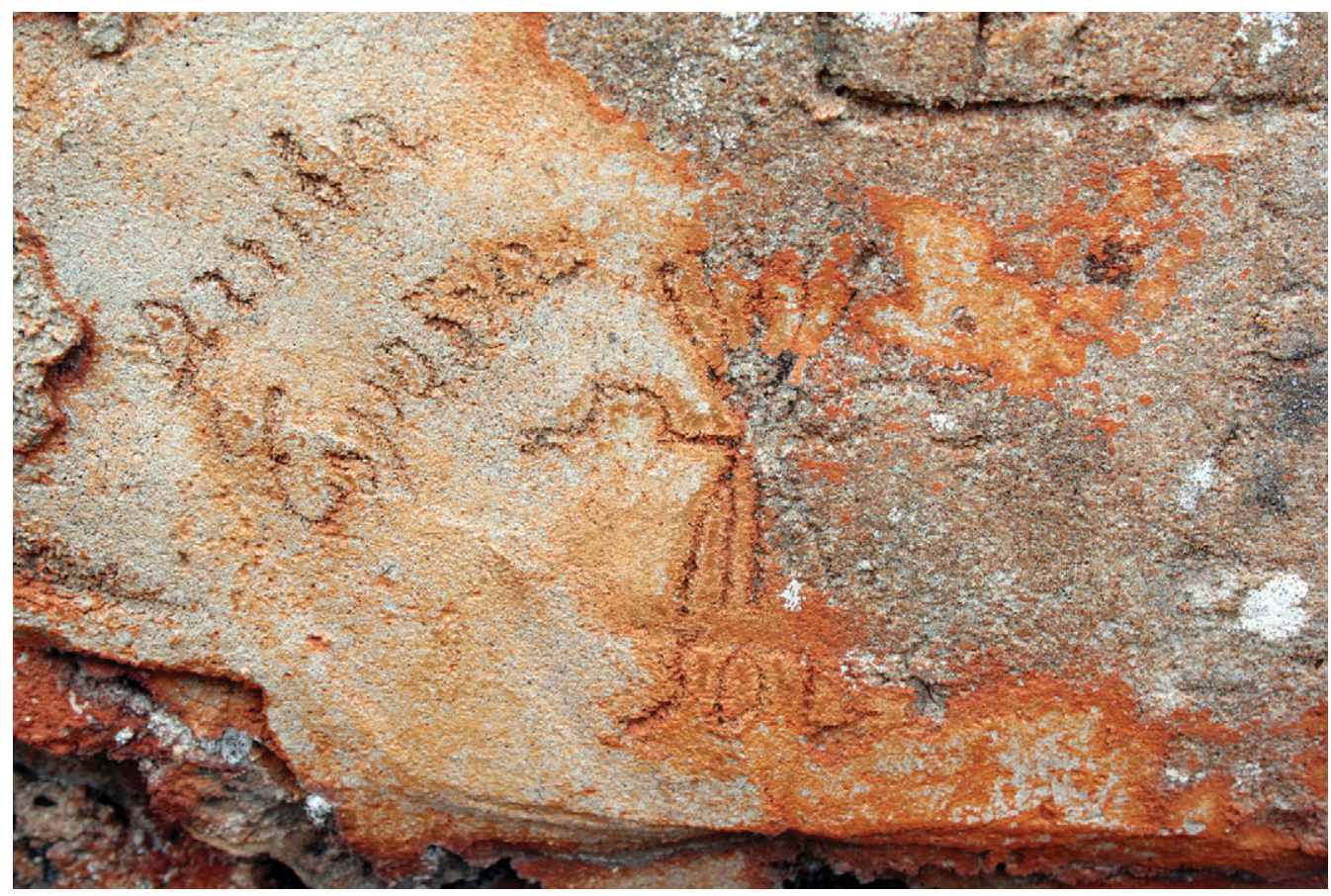

Figure 7. Marking the landscape: a Nationalist graffiti in the fortifications of La Nava. It reads "Hail Spain!" and it has the symbol of the Spanish fascist party (Falange): a yoke and a bundle of arrows.

\section{Theatre of re-education}

The post-war period was a less pleasurable experience for those who were defeated. Half a million Republican soldiers were interned in concentration camps (Rodrigo 2005). Of these, 90000 died of starvation, disease or torture. The new regime established over 100 concentration camps, forced labour camps, prisons and detention centres. The dictatorship worked out a programme aimed at transforming Republicans into law-abiding citizens of the New Spain (Gómez Bravo 2009). This included different levels of punishment, all of which were permeated with religious ideology.

Most concentration camps reused extant buildings, such as schools, bullrings and factories. One of the few newly created was the concentration camp of Castuera the remains of which we studied in 2010. The camp is situated on the main railway line in a remote and desolate area of Extremadura. It was constructed in April 1939 and dismantled one year later (González-Ruibal et al. 2011). Around 15000 people passed through this camp and an unknown number died there (López Rodríguez 2006). The plan of the camp was contained in official records and in a drawing by a prisoner, to which we have now added an archaeological plan (Figure 8). There were two rows of barracks either side of a rectangular parade ground, dominated at one end by a large cross, the concrete foundations of which still survive. In the summer of 2011, archaeologists recovered 18 corpses in a mass grave, interpreted as execution victims. Archaeological investigations have also revealed other aspects of the camp's grim history.

(C) Antiquity Publications Ltd. 

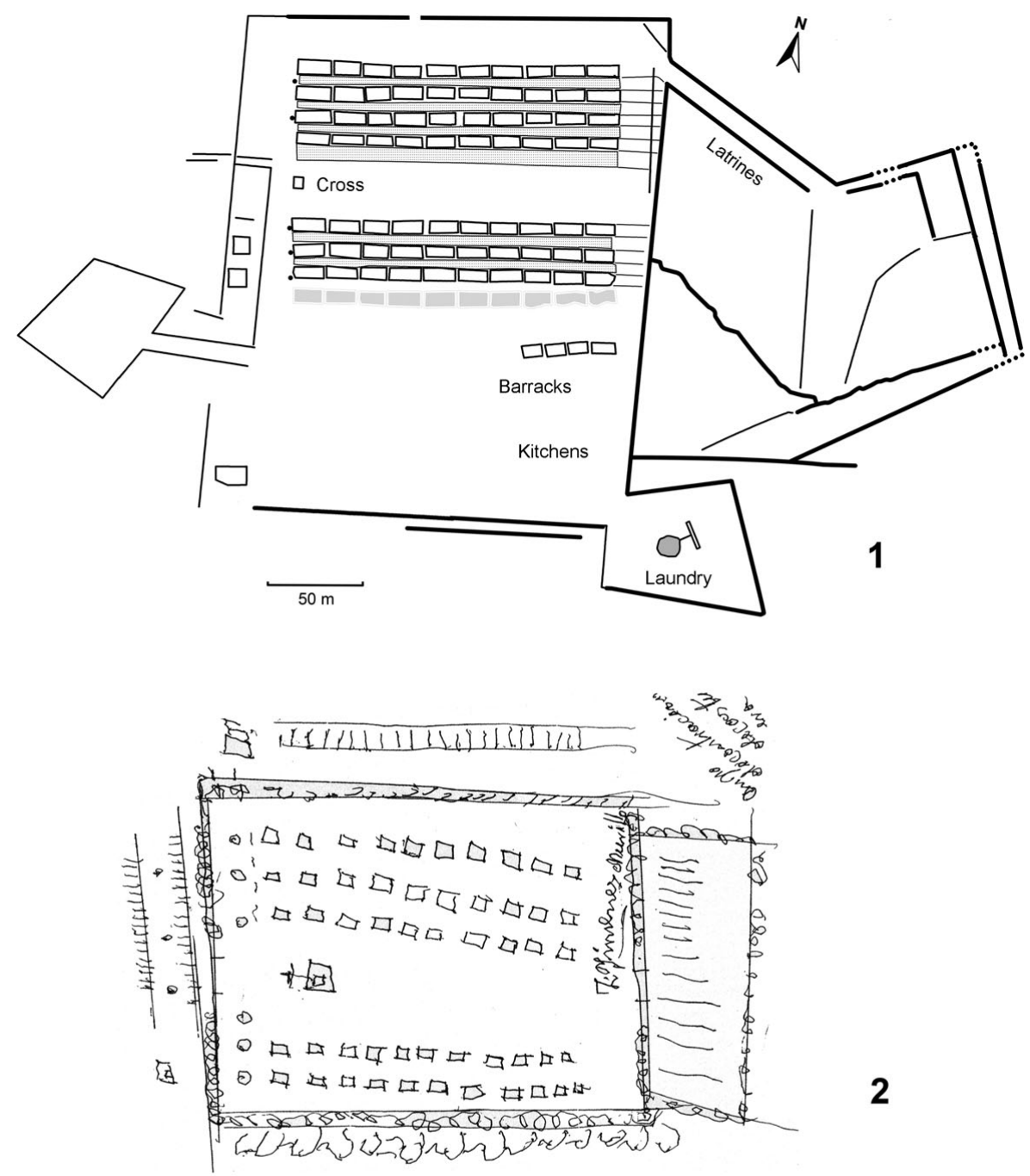

2

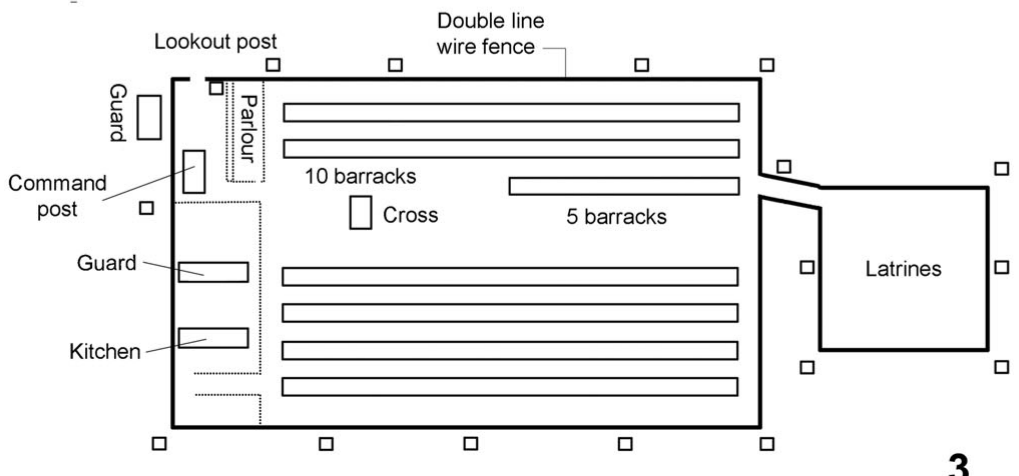

Figure 8. Three visions of the same site: 1) archaeological map; 2) prisoner's map drawn from memory; 3) official map (the labels have been translated into English).

(C) Antiquity Publications Ltd. 

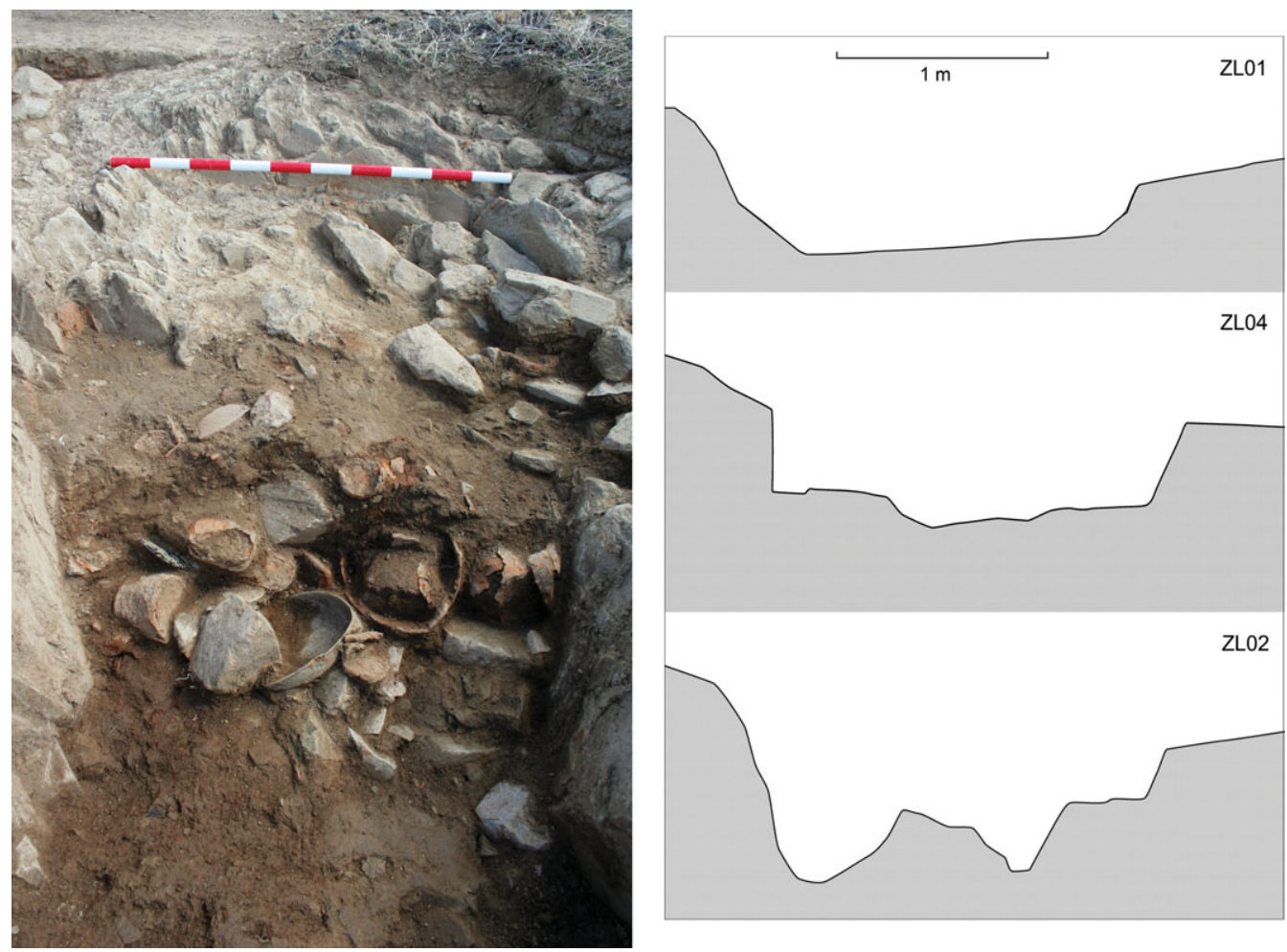

Figure 9. Profiles of the latrines, showing their irregular shape and short depth, and a test pit in one of the ditches, which was backflled with rubbish (including mess tins).

Ditches were dug to delimit the camp, but seemed to have been largely symbolic; in some places they were only $0.2 \mathrm{~m}$ deep. The latrines were located in a conspicuous place, visible from everywhere in the camp and the surrounding area (Figure 8). These took the form of a simple irregular ditch dug through the hard shale, $0.3-0.5 \mathrm{~m}$ deep and c. $2 \mathrm{~m}$ wide (Figure 9). According to the orders issued by the concentration camp service, latrine ditches should be $2 \mathrm{~m}$ deep and $1 \mathrm{~m}$ wide (López Rodríguez 2006: 189); the wide shallow form they actually took would have made them very unhygienic, spreading an awful smell through the camp and increasing the chances of disease in an undernourished population.

The most abundant item found in the latrines and perimeter ditches was the tin can, 90 per cent of which were of either tuna or sardines. There were many potsherds, a lid from a tin pot and several military mess tins, which show the military character of these institutions. Evidence for medicines was plentiful: 22 ampoules, 2 bottles of peroxide, a tube of antiseptic cream and many fragments of medicine bottles, some of them for intestinal diseases.

Few things in the camp identify the prisoners as individual persons, even in the latrines, which are considered to be a good place to find elements of resistance (Myers 2008: 242). Ink bottles symbolise the link between the camp and the outer world. Prisoners were allowed to write letters, which were subjected to strict censorship. In one of the letters that survived,

(C) Antiquity Publications Ltd. 

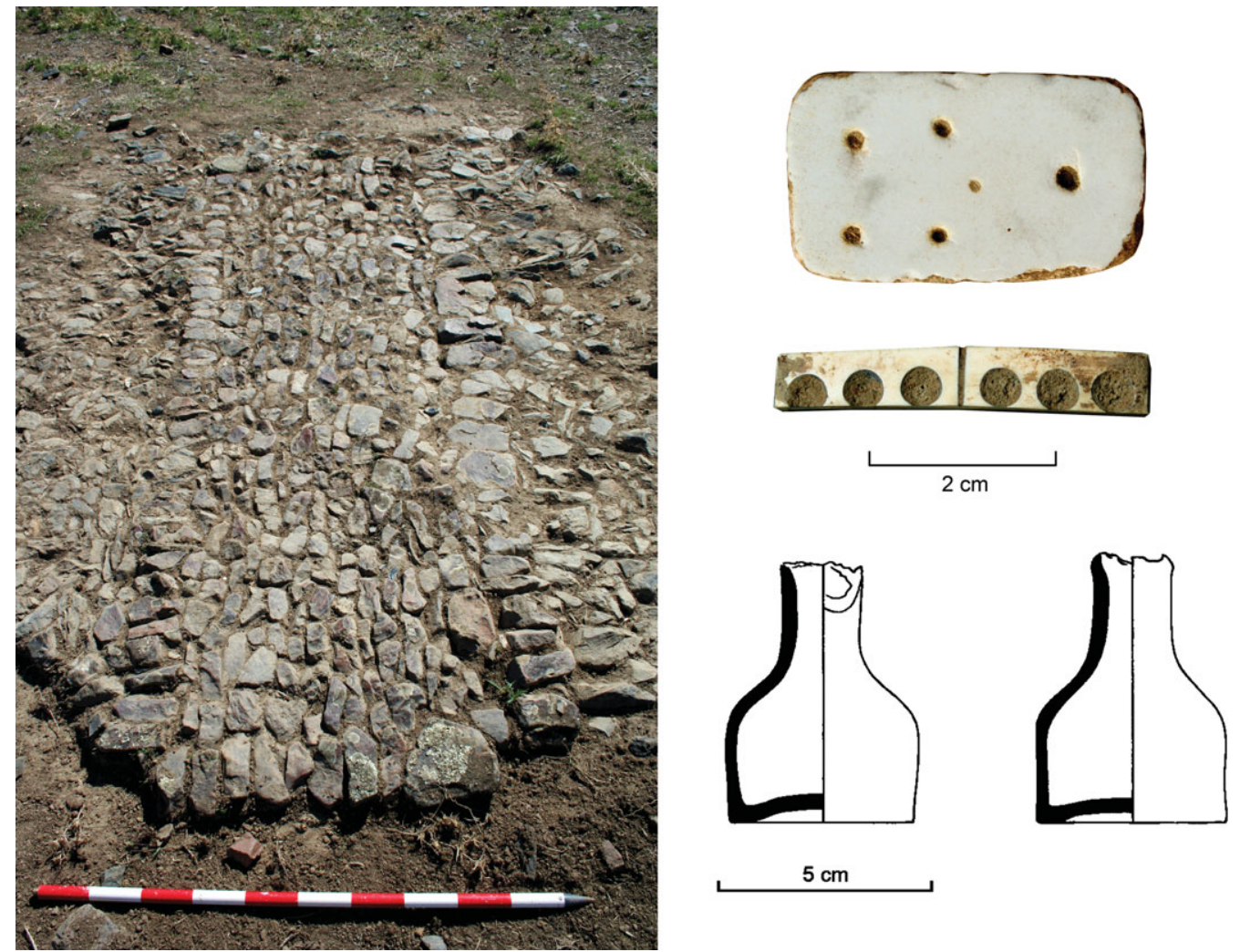

Figure 10. Remaining human in Castuera: a carefully paved entrance to a barrack; hand-made domino pieces; ink bottles for writing home.

a prisoner asked his wife, days before being executed, to send him a ball and some novels to alleviate the boredom (López Rodríguez 2006: 227).

To pass the time the prisoners played dominos with playing pieces made of tile or bone. Making things helped the prisoners to maintain their psychological integrity and, in this way, to maintain an element of resistance against the dehumanising strategies of the camp. There were two interesting testimonies of these subtle acts of resistance, one of which is a finely carved piece of tin, of the type used to cover the prisoners' barracks. The piece bears the name of the barrack, and the quality and style of lettering suggests that the person who made it was perhaps acquainted with printing. A show of skill is also evident in the carefully paved entrance to a prisoners' barrack block (Figure 10). Unlike other entrances and streets, all of which were paved with stones, this one shows a desire to make something aesthetically pleasing. Different types of stones were chosen and assembled to produce a carpet-like effect. The person must have been a mason.

The archaeological investigation endorses surviving accounts of a place notorious for its inhuman repression. The daily diet was confined to a single tin of sardines shared by two or more prisoners, combined with a piece of bread and a watery soup. Only 18 tiny fragments of bones have been identified, confirming that the prisoners had virtually no

(C) Antiquity Publications Ltd. 
access to meat - as opposed to internment camps of other nations (cf. Demuth 2009: 175). It is likely that many prisoners were only saved from starvation by the supplies of food received from relatives (in clay and tin pots such as the ones we found). Absence of family could equal a death sentence.

Testimonies collected from former camp prisoners describe the latrines as an instrument of "moral destruction" (Lafuente 2002: 148) as well as infection. The abundance of medicines is seemingly at odds with a population of mostly young adults, who should be the least affected by illness, but it was precisely the conditions of imprisonment that favoured contagion. When prisoners were treated like animals, showing a skill by doing specialised work was a way of counteracting the prevailing ideology. Historians have studied similar tactics of resistance, but they have invariably focused on artists and intellectuals (Agramunt 2005).

The plaza with its cross is redolent of parades and the relentless process of re-education. Unlike in other fascisms, (Catholic) religion here played an important role in 'healing the Reds'. In modern times, in a reversal of its former role, the foundations of the cross have become a focus of leftist tribute, where prisoners' relatives and members of civic associations gather to commemorate the victims of Francoism.

\section{A country rebuilt by slaves}

Lying behind the contemporary landscape of Spain, with its roads, railways, airports and dams, is a decade of forced labour. Thousands of political prisoners redeemed part of their prison terms by working on public and private infrastructure, an anonymous effort that has passed almost unnoticed (Lafuente 2002). Since 2006, we have been investigating a forced labour camp in Bustarviejo near Madrid (Falquina et al. 2010), where between 1944 and 1952 hundreds of political prisoners laboured in the construction of a tunnel and railway bridge in a mountainous area. The site where the workers lived has survived untouched, with its barracks, staff houses, stalls, quarries and the railway itself now abandoned (Figure 11). The main building had a filthy communal latrine and large communal bedrooms where the prisoners had to sleep crammed on the floor. However, in general the situation was not as harsh as in the concentration camps; after all, this was the last step in the process of rehabilitating the prisoners.

One of the most interesting results has to do with a story that has virtually disappeared from collective memory and from the history books. This concerns the women and children who shared the fate of the vanquished Republican men by following them to their places of imprisonment and lived on the outskirts of the labour camps. While the presence of families was known and is mentioned by some (e.g. Lafuente 2002: 127-28), no research has been conducted into the conditions of their lives. These aspects were eloquently manifested in the archaeological remains of Bustarviejo camp. An entire village was recorded, consisting of huts made by the prisoners and their relatives. The huts were tiny, usually $4-5 \mathrm{~m}^{2}$, much like prison cells (Figure 12). They were built with stone debris from the quarries and had low roofs made from brush. Roofs, walls and floors were reinforced with mortar. The prisoners no doubt obtained the cement from the camp authorities but the quantity was so small that they had to add a large amount of sand. The huts had no windows; all light came from a small door. They had a hearth inside for warmth and for cooking. Beds and benches were (C) Antiquity Publications Ltd. 


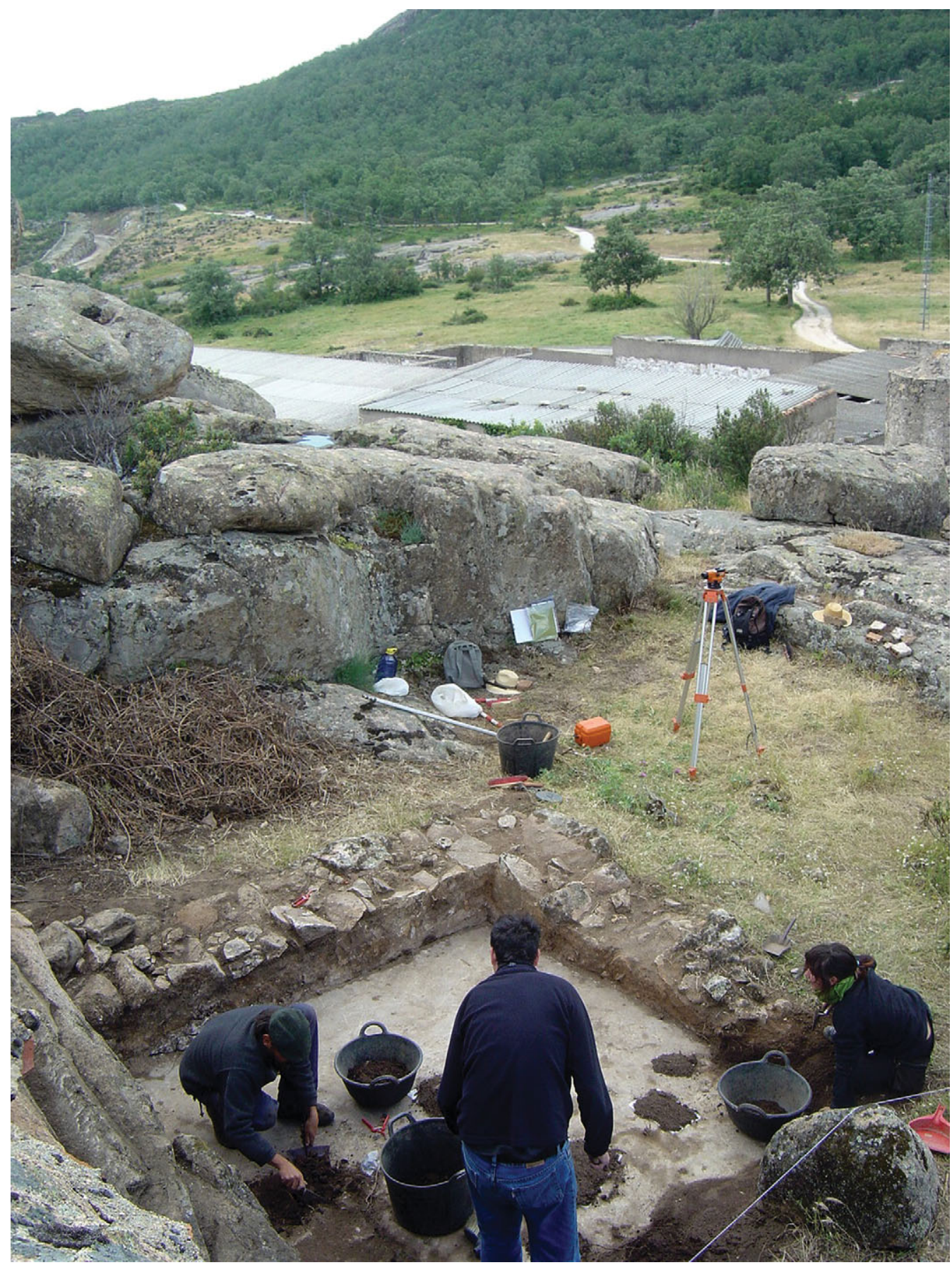

Figure 11. Excavations at the lieutenant's house in Bustarviejo, with the prisoners' barracks behind (after Falquina et al. 2010).

(C) Antiquity Publications Ltd. 


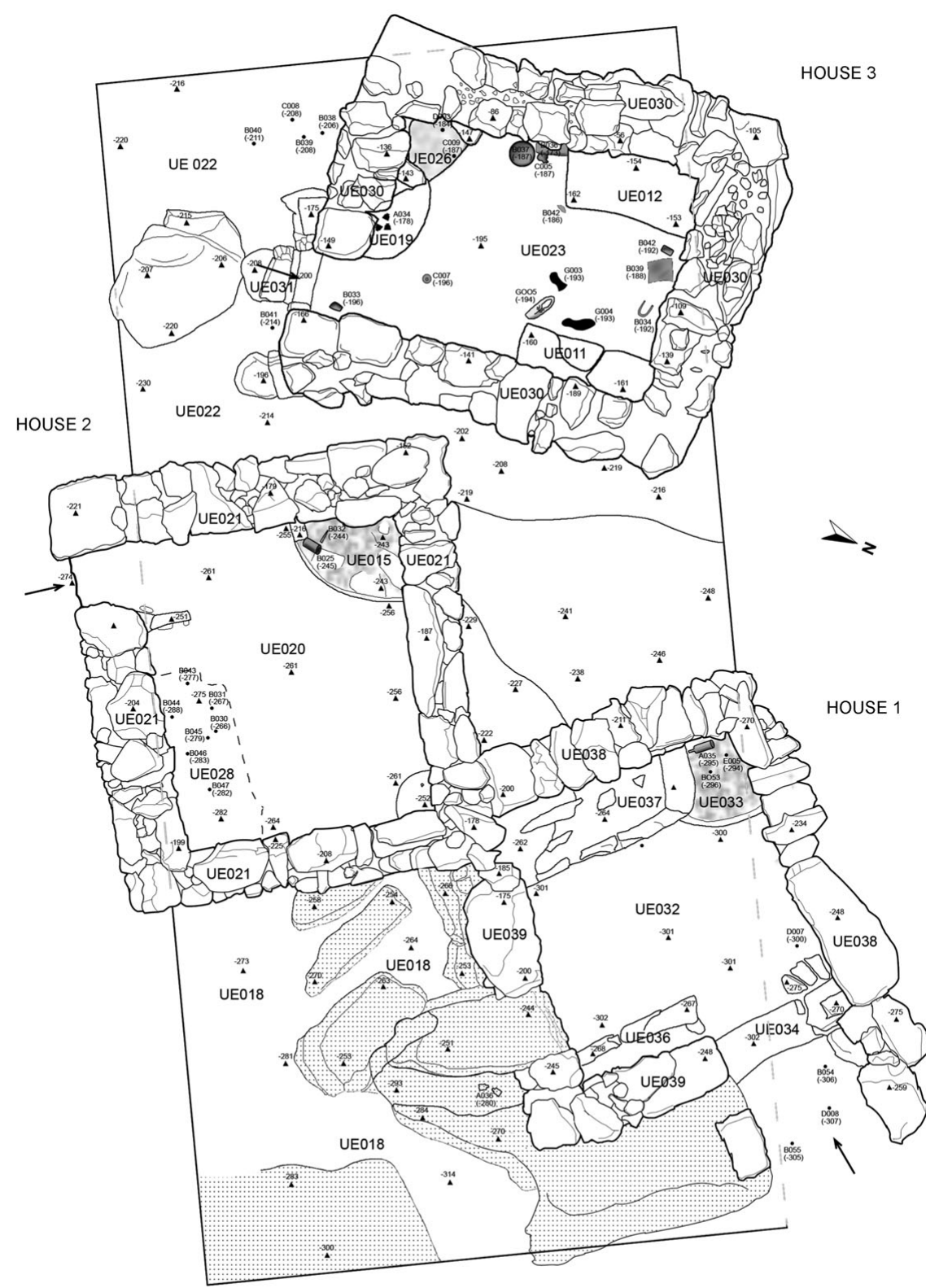

BEDROCK

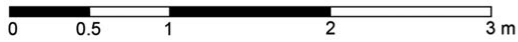

Figure 12. Huts of the prisoners' relatives in Bustarviejo (after Falquina et al. 2010).

(C) Antiquity Publications Ltd. 
made of stone and originally would have been covered with straw or brush. In the cold winters of the Madrid sierra, living in these shacks must have been a terrible experience.

The camp had no barbed wire and all four sentry boxes face outwards. This layout implies that they were devised to detect an external attack by guerrilla fighters and not to control the prisoners. The similar layout and size of the huts suggest some control or consent by authority. Having the relatives close to the prisoners was advantageous to the regime. Families were supported by the prisoners, who received some money for their extra work at the camp and for each relative they had to feed; prisoners thus worked more hours to earn money for their families. Relatives also helped to reinsert prisoners into the social life of the New State-where the Catholic family had an important role to play-while at the same time being stigmatised and punished themselves. Finally, they provided free security. There were escapes from labour camps, but most of the time by young, single persons. Who would flee leaving a wife and children behind? This was a most effective deterrent.

In the 2010 field season, we excavated the house of the lieutenant in charge of the camp garrison (Figure 11). The house was considerably better than that of the prisoners: it had an area of $15 \mathrm{~m}^{2}$, a tiled roof and a floor of polished concrete. The walls were painted and had windows. At the same time, the building shows the extent to which the war had worsened the living conditions of most Spaniards, both victors and the vanquished. The lieutenants' house was little better than a shack, without water, electricity or lavatory, and in all likelihood was cold and damp.

Bustarviejo camp was closed in 1952. Its prisoners were finally released but they were subjected to constant surveillance by the police and by their own neighbours (Gómez Bravo 2009). The world they found outside the prison was very different from that of 1936 . The built environment had changed: Nationalist memorials and buildings had emerged everywhere. Razed villages and neighbourhoods had been reconstructed in a rigid, modernist style, fashionable among dictatorships: a bleak, alienating architecture. Many of these were built by political prisoners. Streets and towns had been re-named after Franco and his generals. Every corner of the country and every element of material culture-from tin cans to churches - were marked with symbols of the fascist party: the same yoke and arrows that an anonymous soldier once scribbled on a pillbox, when the fate of the war was still uncertain.

\section{Conclusions}

Archaeology can make three important contributions to the understanding of civil war and dictatorship in Spain. In the first place, it can deconstruct familiar geographies that have been produced through processes of symbolic violence. Archaeology exposes the trauma that lies underneath the foundations of contemporary landscapes, the stories that have been silenced, such as the defence of the University of Madrid during the war, or forgotten, such as the experiences of women and children in labour camps. Second, archaeology is well positioned to modify the version of history that presents the Republic and the Civil War as a single phase (1931-1939) concluded by Franco's peace. Archaeological research shows that the period 1936-1950 was part of the same traumatic episode of material change - resulting in a tortured landscape of trenches, bunkers, mass graves and prisons. Third, archaeology 
can collaborate in producing a social history of the war, so far less developed than the political and military histories. As for the First World War (e.g. Robertshaw \& Kenyon 2008), archaeological remains reveal aspects of daily, intimate lives in the trenches in a poignant way. Archaeology rescues microhistories that are revealing of the nature of the war on both sides. Material culture, however, also tells about macrohistory: under archaeological scrutiny, the landscapes and activities of the Spanish Civil War look much more similar to those of the First World War than the Second, despite the historiographical tenet that the conflict was the prelude of the second global conflagration. The armies of Spain look almost preindustrial, with their vernacular stone pillboxes and makeshift uniforms. Archaeology shows that the threads of history are always multiple and intertwined. This may not change grand historical narratives, but it can allow us to see and understand them differently.

\section{Acknowledgements}

Fieldwork was funded by the Spanish National Research Council, the Research Council of Norway (Ruin Memories Project, directed by Bjørnar Olsen), the Spanish Ministry of the Presidency and the Complutense University of Madrid. I would like to thank all the colleagues who have made this project possible between 2008 and 2010. Their names appear in the bibliography. Two anonymous reviewers provided helpful comments that have improved the article.

\section{References}

Agramunt, F. 2005. Arte y represión en la guerra civil española: artistas en checas, cárceles y campos de concentración. Valencia: Generalitat Valenciana; Valladolid: Junta de Castilla y León.

ARTHUR, M. 2009. The real Band of Brothers. First-hand accounts from the last British survivors of the Spanish Civil War. London: Collins.

Demuth, V. 2009. 'Those who survived the battlefields'. Archaeological investigations in a prisoner of war camp near Quedlinburg (Harz/Germany) from the First World War. Journal of Conflict Archaeology 5: 163-81.

Falquina, A., J. Rolland, C. Marín, G. Compañy, A. GonzÁlez Ruibal, A. Quintero \& P. Fermín. 2010. De estos cueros sacaré buenos látigos. Tecnologías de represión en el destacamento penal de franquista de Bustarviejo (Madrid). Ebre 38. Revista Internacional de la Guerra Civil 1936-1939 5: 247-71.

FERRÁNDIZ, F. 2006. The return of Civil War ghosts: the ethnography of exhumations in contemporary Spain. Anthropology Today 22(3): 7-12.

Gómez Bravo, G. 2009. El exilio interior. Cárcely represión en la España franquista (1939-1950). Madrid: Taurus.

GonZÁleZ-Ruibal, A. 2011. Digging Franco's trenches: an archaeological investigation of a Nationalist position from the Spanish Civil War. Journal of Conflict Archaeology 6: 96-122.
GonzÁlez Ruibal, A., C. Marín, M. SÁnChez-Elipe \& S. LORENTE. 2010. Guerra en la universidad. Arqueología del conflicto en la Ciudad Universitaria de Madrid. Ebre 38. Revista Internacional de la Guerra Civil (1936-1939) 4: 123-44.

González-Ruibal, A., G. Compañy, A. Franco, A. Laíño, C. Marín, P. Martín, I. Martínez, A. Rodríguez \& A. GÜIMIL. 2011. Excavaciones arqueológicas en el campo de concentración de Castuera (Badajoz). Primeros resultados. Revista de Estudios Extremeños 67(2): 701-749.

Heiberg, M. \& P. Mogens. 2005. Los negocios de la Guerra. Armas Nazis para la República española. Barcelona: Crítica.

LAFUENTE, I. 2002. Esclavos por la patria. La explotación de los presos bajo el franquismo. Madrid: Temas de Hoy.

LÓpez Rodríguez, A. 2006. Cruz, bandera y caudillo. El campo de concentración de Castuera. Badajoz: CEDER-La Serena.

MosHENSKA, G. 2008. A hard rain. Children's shrapnel collections in the Second World War. Journal of Material Culture 16(2): 107-125.

MYERS, A. 2008. Between memory and materiality: an archaeological approach to studying the Nazi concentration camps. Journal of Conflict Archaeology 4: 231-45.

Quintero, A., L. Villaescusa, S. Gómez, C. Martínez, S. García \& M. Cantabrana. In press. La Ciudad Universitaria de Madrid: espacio, materialidad, guerra y reconstrucción. Ebre 38. Revista Internacional de la Guerra Civil 5.

(C) Antiquity Publications Ltd. 
RENSHAW, L. 2011. Exhuming loss: memory, materiality and mass graves of the Spanish Civil War. Walnut Creek (CA): Left Coast.

Reverte, J. 2004. La Batalla de Madrid. Barcelona: Crítica.

Robertshaw, A. \& D. Kenyon. 2008. Digging the trenches. The archaeology of the Western Front. Barnsley: Pen \& Sword.

Rodrigo, J. 2005. Cautivos. Campos de concentración en la España franquista, 1936-1947. Barcelona: Crítica.
SAUNDERS, N.J. 2001. Matter and memory in the landscapes of conflict: the Western Front 1914-1999, in B. Bender \& M. Winer (ed.) Contested landscapes: movement, exile and place: 37-53. Oxford: Berg.

SAUnders, N.J. \& N. FAUlKNER. 2010. Fire on the desert: conflict archaeology and the Great Arab Revolt in Jordan, 1916-18. Antiquity 84: 514-27.

SCHOFIEld, J. 2005. Combat archaeology. Material culture and modern conflict. London: Duckworth.

SEIDMAn, M. 2002. Republic of egos. A social history of the Spanish Civil War. Madison (WI): University of Wisconsin Press.

Received: 23 June 2011; Accepted: 9 August 2011; Revised: 7 November 2011 